\title{
Employment Management Policies in Single-industry Towns in the Light of Existing Issues of Precarious Employment
}

Submitted 18/08/19, 1st revision 27/09/19, 2nd revision 30/10/19, accepted $21 / 11 / 19$

\author{
O.N. Bykova ${ }^{1}$, A.P. Garnov ${ }^{2}$, P.V. Stroev ${ }^{3}$, O.V. Pivovarova ${ }^{4}$
}

\begin{abstract}
:
Purpose: The article aims to study the precarious employment in single-industry towns and to assess the effectiveness of government measures aimed at reducing it and ensuring the protection of economic and social rights of workers.

Design/Methodology/Approach: It was revealed that the transition to an information-digital society, which continues to be formatted at the junction of changes in communication technologies and the motivation of employment behavior, has significantly changed the labor market in Russia. There was a massive introduction of non-standard forms of employment, which has not only positive effects, but also negative risks that are most acute in singleindustry towns. To minimize these risks, it is necessary to find mechanisms to increase the economic and social security of workers with flexible employment.

Findings: The paper proposes to develop an employment management policy in singleindustry towns regarding the precarious employment and include measures of solving the issues related to self-employment of the population.

Practical Implications: The practical results of the study can be used to develop assumptions for regional authorities to reduce precarious employment in single-industry towns.

Originality / Value: The main contribution of this study is that single-industry cities should reduce inefficient "social employment" by creating highly efficient jobs and developing selfemployment.
\end{abstract}

Keywords: Precarious employment, single-industry towns, informal employment.

JEL Code: J11, J29, E24.

Paper type: Commentary review: Employment Management.

\footnotetext{
${ }^{l}$ Department of Entrepreneurship and Logistics, Plekhanov Russian University of Economics, e-mail: bykova.on@rea.ru, https://orcid.org/0000-0002-7671-7994.

${ }^{2}$ Department of Industrial Economics, Plekhanov Russian University of Economics, e-mail: profgarnov@yandex.ru, https://orcid.org/0000-0003-1435-8698.

${ }^{3}$ Center for Regional Economics and Inter budgetary Relations, Financial University under the Government of the Russian Federation, https://orcid.org/0000-0003-4770-9140.

${ }^{4}$ Center for Regional Economics and Inter budgetary Relations, Financial University under the Government of the Russian Federation, https://orcid.org/0000-0002-1755-5972.
} 
124

\section{Introduction}

The importance of single-industry towns for the Russian economy is obvious, despite ongoing discussions regarding the practical effect of such a production, where singleindustry municipalities (single-industry towns) emerge. The current list includes 319 single-industry towns, where more than 13 million people live (about $9 \%$ of the Russian population). One of the burning social and economic issues in single-industry towns is informal employment, one of the forms of precarious employment.

According to the methodology used by the Federal State Statistics Service, informal employment refers to employment at an undertaking that does not have state registration as a legal entity (employed by individuals, self-employed, employed in the household). A more specific definition of informal employment is all forms of employment (for hire or not) that are paid, not formally registered, not considered by the organization's statistics and tax authorities, and are not regulated by regulatory enactments and legal structures (Bykova et al., 2018). Precarious employment is the forced loss of a standard employment relationship by an employee based on a fulltime employment contract. They are replaced by urgent employment, part-time employment, fictitious self-employment and agency contracts (Bykova and Suslova, 2011).

The modern period is characterized by the expansion of unsustainable forms of employment (Bobkov, 2017). The widespread use of remote work, which is part of the process of decentralization of work in time and space, creates a flexible virtual labor market.

\section{Labor Market in Single-industry Towns}

The term "single-industry town" was defined in the Federal Program for State Support of Small Business in the Russian Federation for 2000-2001. Pursuant to the Regulation No. 1001 issued by the Government of the Russian Federation on August 29, 1994, an undertaking is principal employer and mainstay of an entire town that employs at least $30 \%$ of the total number of people employed by the business, or which has social and communal services and engineering infrastructure facilities on its balance sheet that serve less than $30 \%$ of inhabitants. Currently, one of the burning social and economic issues in single-industry towns is hidden unemployment and precarious work (Fedchenko, 2014).

Hidden unemployment covers persons who are employed formally (an employee is only on the staff), and part-time employed or who are on compulsory leave, without paying them wages. Consequently, hidden unemployment is most often an evidence that the employee faces (Crying, 2005). Unlike the crisis of 2008-2009, when official unemployment rates were much higher, this form of unemployment is more typical of the current situation. It manifests itself in increasing the indicators of 
underemployment and overdue salary arrears, forcing the employees to quit at their own will and to move to informal employment (Crying, 2005).

In a crisis, it is expensive to maintain the entire staff, is simply impossible to fire employees, and is costly to reduce quite several employees and pay them appropriate compensation. Therefore, many employers must take various tricks, while continuing to maintain the illusion of employment in order to avoid social tension (Maslova, 2011). Informally employed and economically inactive people have a higher chance of joining the unemployed than formally employed ones (Kotvanova, 2014). The size of informal employment in Russia is much higher than in most developed countries and is comparable with the shadow labor market in developing countries, where its share is from 25 to $45 \%$. At the same time, $90 \%$ of these workers are exclusively employed in the informal sector (Glinskaya, 2018).

According to the ILO, the main challenge for both the Russian and global labor markets is not unemployment, but precarious employment, which creates risks for lower wages, lower productivity and social protection. According to ILO estimates, about one third of all workers in Russia work beyond the standard labor relations with the employer: $20 \%$ are informally employed, $10 \%$ are temporarily employed (Bykova and Suslova, 2011). The attractiveness of precarious employment for the employer is associated with the surplus value taken by capital due to the reduction of costs per hour of labor when using temporary workers in comparison with regular workers. Maintaining or increasing the rate of surplus value by capital when using temporary, seasonal hiring or other forms of precarious work turns into a more attractive form of hiring for the employer that makes it possible to put the risks of labor relations on the hired worker (Bykova and Ermolaeva, 2018).

The concern of the international scientific community with the spread of precarious employment lies in developing new models of labor and entrepreneurial relations that are adequate to current and future means of labor and will ensure the social protection of the employee (Hermann and Kalaycioglu, 2011). Recognizing the spread of nonstandard forms of employment as opposed to systemic unemployment, the ILO coined the term "precarization" and defined the legal norms of contractual relations between an employee and an employer: a limited duration of the contract, the nature of the employment relationship, and non-standard conditions.

The precarization of job relations is an objective process of forming a certain economic layer (precariat) by means of the redistribution of previously existing sociodemographic costs of the economically active population based on the gradual displacement of standard (already established) forms of employment by atypical forms (Crying, 2005). The formation of precariat is associated with the development of new forms of job relations. Owing to the transition to such forms, working life is saturated with uncertainty, workers become more individualized and vulnerable, and all this forms one of the sides of precarization (Bauman, 2005). 
One of the key features of the precariat is the status of a temporary worker. Members of this group are deprived of professional self-identification, several guarantees related to work and suffer from status dissonance (Standing, 2011). For many years, the main source of precariat formation in Russia was the self-employed population. The number of such persons was small and did not change the overall picture of the job market of persons entering labor relations with the employer. However, from January 1, 2016, the rate of growth of the precariat in Russia started to escalate, and the number of precariat reached a value when it began to threaten the production, the labor market, and the entire Russian society. Now about 13-20 million people are completely deprived of social protection from the economic and social consequences of disability and their number is growing rapidly (Fainburg, 2017).

In view of the above, employment management policies in single-industry towns should be put in place regarding the issue of precarious and informal employment, and include measures aimed at finding solution to it (Zvyagintseva et al., 2018). Tensions in the job market of single-industry towns are characterized by migration flows. General indicators of migration include the number of arrivals and the number of departures. The balance of migration is the difference between the number of arrivals and the number of departures, the migration turnover is their sum (Rybakovski, 1987).

The share of the able-bodied population increases if migration growth is observed in the town, i.e., it is the able-bodied population that arrives at the settlement. The stable connection of the productive attribute with the number of undertakings and businesses is confirmed by the fact that the population is attracted by the choice of various objects of employment or there are favorable conditions for creating their own organization (Aksyanova and Chekhlomin, 2018).

The crisis of the job market in single-industry towns is evidenced by the increased migration outflow of people who are forced to find jobs in other regions. The most active and ambitious people leave the location, and only the passive population decides to stay driven by a dependent mood, depression, pessimism caused by the lack of alternatives. All this leads to an even greater decrease in the prospects for the development of entrepreneurship and diversification of the town (Aksyanova and Chekhlomin, 2018).

Problems of single-industry towns exist not only in the Russian Federation, but also in the countries of Europe, the USA, China and Japan. In Germany, diversification of production and resettlement of single-industry towns goes on; environmental problems are solved through the upgrade of production facilities. In addition to refinancing, restructuring, and technological upgrades, Canada has taken a "compression management" approach. The US put the Reduction for Survival program in place. It involves the demolition of the poorest cities and the return of the area to nature. The program itself affected the city of Flint near Detroit. In addition, there is a reduction in spending by reducing the number of municipalities. Some of 
the US states, on the contrary, creates a business environment and tourist, cultural centers based on former single-industry towns (Peredelskaya, 2016).

According to the authors, the approach used in Germany and the USA (resettlement of single-industry towns) should not be applied in Russia without reasonable background. The grid of cities in Russia is already too rare, and a single-industry town is often the trade, distribution and organizational center of the adjacent territory.

\section{How to Solve the problem of Employment in Single-industry Towns}

In 2009-2016, measures of backing single-industry towns were realized mainly as part of the execution of instructions of the President and the Government of the Russian Federation. In regions, the integrated investment programs were progressed under the leadership of the working groups that focused on the modernization of city-forming undertakings, diversification and development of small and medium-sized businesses, which were discussed at meetings of the Interdepartmental Working Group and, after approval, were sent to the Ministry of Finance of Russia from review (Oganyan and Streltsov, 2008). The number of single-industry towns with the most difficult socioeconomic situation since 2014 to 2016 increased from 75 to 100 .

According to Rosstat, 3217 thousand people, or $25 \%$ of the population of singleindustry towns of Russia, lived in the least prosperous single-industry towns in 2016. Another 5620 thousand people (43\% of the population of single-industry towns) lived in cities with risks of worsening socio-economic conditions. In the "stable" singleindustry towns, only 4188 thousand people lived, or $32 \%$ of the population of singleindustry towns. Thus, generally, more than $2 / 3$ of the population lives in Russian single-industry towns where the socio-economic situation is already extremely difficult, or there are risks of its deterioration. Most of the largest single-industry towns with a population of more than 200 thousand people belong to cities with a stable position (Repnikova et al., 2019).

In economically "stable" single-industry towns, the population is on average higher than in less prosperous cities. The average population of the cities of the "green" zone at the beginning of 2016 was about 60 thousand people, and the cities of the "red" and "yellow" zones amount to 34-36 thousand people. There are single-industry towns in 61 of the 85 constituent entities of the Russian Federation, but they are mostly concentrated in the Volga Federal District and the Siberian Federal District. Almost half of Russian single-industry towns are located within these federal districts (79 cities in the Volga Federal District and 66 in the Siberian Federal District), in which more than half of the total population of single-industry towns live. If on average in the country, 9-10\% of the population lives in single-industry towns, this indicator takes $14 \%$ in the regions of the Volga Federal District, and 16\% in the Siberian Federal District. In addition, in regions there is a significant number of "problematic" singleindustry towns. 
So, in seven constituent entities of the Russian Federation (Kemerovo, Chelyabinsk, Vologda, Sverdlovsk, Arkhangelsk regions, the Republic of Khakassia, the Republic of Tatarstan) the situation with the state and development of single-industry towns is of particular importance, since in these regions the proportion of the population living in single-industry towns exceeds $25 \%$, while the national average is $9 \%$.

According to the information available to the Ministry of Finance, since 2010 in single-industry towns backed by the state in 2010-2011, 98074 additional permanent jobs were created, the amount of extrabudgetary investments attracted amounted to 476.8 billion rubles, the registered unemployment rate dropped from $2.4 \%$ to 1.6 percent (Ustinova and Gordievskaya, 2016). In 2014, in order to implement integrated investment programs that ensure the diversification and development of the economy of single-industry towns, the Fund for Development of Single-industry Towns was established. Since 2014, direct state support of single-industry towns has been provided through this institution.

According to the Rules for granting subsidies, federal budget funds are allocated to the Fund in order to provide the necessary conditions for creating new jobs that are not related to the activities of city-forming business, attracting investments in singleindustry towns and developing the urban environment.

In 2014-2017, the fund was fueled with subsidies from the federal budget in the total amount of 21.2 billion rubles. Cash execution of expenses amounted to 11.9 billion rubles $(56.2 \%)$. Due to the lack of need for subsidies, 3.3 billion rubles were returned to the federal budget. As of January 1,2018, the remainder of the subsidy amounted to 6 billion rubles, of which 1.9 billion rubles were spent in January-August 2018 (according to current data). For 2018, the Fund is provided for another 3.6 billion rubles. However, as of September 1, 2018, an agreement on the provision of a subsidy between the Ministry of Economic Development and the Fund was not concluded, since the lack of sound planning of budget allocations to the Fund to support singleindustry towns in 2014-2016 led to significant amounts of unused funds: as of January 1, 2016 - 5808.8 million rubles, as of October 1, $2016-4068.5$ million rubles. The number of subsidies not used by the Fund as of January 1, 2017 amounted to 1224.1 million rubles (19.8\% of funds received).

According to the Fund's report on the achievement of targets for the efficiency of the use of subsidies as of January 1, 2017, the number of created jobs in single-industry towns backed by the subsidy amounted to 2,401 units, which exceeds the planned values by more than 9 times. The volume of attracted investments amounted to 16573287.2 thousand rubles, which exceeded the planned indicators by more than 33 times. At the same time, the data of the control and expert-analytical measures indicate that the Fund's efficiency indicators for the use of subsidies by the volume of attracted investments and created new jobs in single-industry towns are given for investment projects that are not classified as "new investment projects" and are not interrelated 
with the results of the measures for the construction of infrastructure in single-industry towns, and cannot be indicators of the performance of the Fund's investment.

In 2016, the certificate of the priority program "Integrated development of singleindustry towns" issued by the working group on the modernization of single-industry towns under the Government Commission on Economic Development and Integration, the Ministry of Economic Development of Russia and the Fund was approved. For introduction of the program for 2017-2020, 25.3 billion rubles were allocated, but in 2017 expenses were paid in the amount of 4.4 billion rubles, that is, only $39.1 \%$ of the planned amount for this year. The target of the Priority Program to create 230 thousand new jobs by the end of 2018 was achieved at the beginning of 2018. However, the objectivity and reliability of the achieved indicators is doubtful, since, for example, when calculating the created jobs, temporary places and places created independently of the program events were considered (Nikolaeva, 2018).

For example, in the Kirov region, where, according to reports, 4186 jobs were created in 11 single-industry towns (147\% of the planned value for 2017). Moreover, more than $40 \%$ were temporary jobs for minor citizens. In fact, only in 5 single-industry towns of the region (Belaya Kholunitsa, Kirs, Krasnaya Polyana, Luza, Strizhy) the unemployment rate exceeds the average Russian indicator and the Kirov region by two or more times. The number of people who left single-industry towns of the Kirov region is 7.2 thousand in excess of the number of arrivals.

In order to ensure the socio-economic development of single-industry towns by attracting investments and creating new jobs that are not related to the performance of city-forming business, Article 34 of the Federal Law No. 473-FZ of December 29, 2014 On Territories of Advancement of Socio-Economic Development in the Russian Federation stipulates the procedure for creating a Priority Social and Economic Development Area in the territories of single-industry towns. Priority Social and Economic Development Area residents in single-industry towns are provided with tax benefits, preferential rates of insurance contributions to non-state extra-budgetary funds, and a facilitated procedure for conducting state and municipal control. As of December 1, 2017, 78 residents of Priority Social and Economic Development Area, including 37 single-industry towns were entered in the Register.

According to the Unified list of single-industry towns support measures issued by the Ministry of Economic Development of the Russian Federation, the existing singleindustry towns support system envisaged the implementation of more than 100 financial and non-financial support measures. According to the Federal Treasury, for the period 2010-2016, the volume of gratuitous receipts to single-industry towns from other budgets of the budget system of the Russian Federation amounted to 1028994.4 million rubles, of which: subventions $-58.5 \%$, subsidies $-27 \%$, subsidies $-11.1 \%$. For the indicated period, the annual volume of gratuitous receipts to single-industry towns increased from 111027.0 million rubles in 2010 up to 177802.4 million rubles in 2016 , or $60.1 \%$. 
According to the Management system, the population of single-industry towns decreased by 181.5 thousand people and amounted to 13507.9 thousand people in 2015. In 2016, due to natural decline and migration outflow, the population of singleindustry towns decreased by another 49.9 thousand people and amounted to 13458.0 thousand people, i.e. the no inflow of labor resources.

In some cities, the population has grown markedly. The reasons for the growth, however, may be different. For example, in Yurg, population grew due to the inflow of contracted military personnel. In most single-industry towns with Priority Social and Economic Development Area status, since 2015 to 2016 population growth was negative (Dobrycheva, 2018). In many single-industry towns, the unemployment rate is higher than the average in Russia. The registered unemployment rate in singleindustry towns in November 2017 ranged from $0 \%$ to $13.5 \%$ with a median value of $1.1 \%$. However, it can be assumed that the actual unemployment rate is much higher. The average number of employees of all organizations by single-industry towns for 2017 amounted to 4.098 million people, which is $4 \%$ less than in 2016.

On average in Russia, $75 \%$ of respondents are looking for full-time jobs, 53\% with good salaries, and $17 \%$ in their specialty. Most residents of single-industry towns $(80 \%)$ are quite pessimistic and believe that finding the required job is quite difficult. On average in Russia, 78\% of respondents think so. As of January 1, 2017, 53.3 thousand workers were in the enterprises of single-industry towns in the part-time mode, including 5.8 thousand people were idle.

A survey of residents of 60 single-industry towns conducted by the Accounts Chamber showed that about $60 \%$ of the population assess the unemployment rate in their municipality as "high" or "very high" (for comparison: in the framework of the sociological survey of the Federal Guard Service of the Russian Federation conducted in December 2015, - 43\%). Half of the respondents (48\%) believe that it is "impossible" to find decent work in their city, more than $40 \%$ - "probably with difficulty" (for comparison: more than a third of the respondents considered this in the Federal Guard Service survey). Only $6.8 \%$ of residents of single-industry towns believe that it is "possible" to find a decent job. It should be noted that the main group of respondents was the working population (77.4\%) aged 19 to 50 years $(80.5 \%$ of the number of respondents).

According to the results of the survey, more than $50 \%$ of the population of singleindustry towns are ready to apply to the employment service in case of loss of work and more than $30 \%$ are not ready. According to the comments of the respondents, the main reason for the refusal to apply to the employment service is the lack of offers of qualified and adequately paid vacancies (Odegov and Babynina, 2018). Thus, the indicator "Level of registered unemployment to the economically active population" does not reflect the real picture in solving the problem of unemployment in singleindustry towns. 
The current trend towards a decrease in the number of employees and at the same time an increase in the number of pensioners leads to changes in the structure of the population of the city. It begins to dominate the proportion of people over working age (Chelpanova and Grevtsova, 2018). In several single-industry towns, the number of residents of retirement age exceeded the number of employees (Garifullina, 2014).

In single-industry towns, the main industries requiring workers include manufacturing, security, trade, and medicine. Less need for workers in transport and construction. The most popular in these single-industry towns are low-skilled specialties, and Priority Social and Economic Development Area residents are not included in the list of large employers (Dobrycheva, 2018). The five most popular professions are a loader, cleaner, seller, nurse, driver. However, most of the professions declared hardly require even secondary vocational education. Thus, in single-industry towns, a layer of the intelligentsia and highly skilled workers are "washed out" (Repnikova et al., 2019).

On the labor markets of single-industry towns, there is a disproportion in supply and demand. A significant proportion of the workforce is off the books or informally unemployed. One of the problems of employment remains the inefficient use of officially employed labor (hidden unemployment) (Kotvanova, 2014).

Given the above, it is necessary to dwell especially on the problem of self-employment of the population. Estimates of the number of self-employed citizens vary greatly, but it is obvious that tens of millions of people are counting. It is customary to classify self-employed citizens as individuals providing certain types of services to individuals without registering as an individual entrepreneur. This can be the services of a nanny, a nurse, a tutor, domestic services, home repair services, programming and computer assistance, services of a driver, photographer, translator, hairdresser, designer and others.

According to a survey conducted by the National Agency for Financial Studies, one in five (18\%) Russians work "for themselves", and for $11 \%$ of the population this is the only source of income. The incomes of the vast majority of the self-employed are in the background. However, so far, attempts to legalize the self-employed have not been completed with success. According to the Federal Tax Service, at the end of the first quarter of 2018, the number of registered self-employed in the country was only 1289 people.

A patent system that replaces three taxes at once - value added tax, personal income tax and personal property tax, could become an effective tool for legalizing selfemployed citizens. Nevertheless, according to the conclusions of the Accounts Chamber, the self-employed of a patent are now scared away by a high level of fiscal burden. In addition, the need to extend a patent for each type of activity or in each region to buy a new patent hinders the distribution of a patent. 
In modern conditions, many professions are rapidly disappearing and at the same time, there are completely new ones associated with digital technology. On the one hand, this trend negatively affects the employment of the population, whose competencies are rapidly devaluing. On the other hand, thanks to digital technologies, employment problems for single-industry towns can be solved through a new, progressive form of employment - remote work. Employees of many areas no longer need to be close to the employer (programming, design, layout, marketing, business services, engineering, etc.). Currently, the Digital Economy program is being implemented in Russia, one of the areas of which is Human Resources and Education. Among the goals of this area is the improvement of the education system, which should provide the digital economy with competent personnel.

Soon, as part of the "Personnel and Education", the introduction of digital certificates will begin to assimilate the key competencies of the digital economy by the general public. Since 2019 in pilot regions, 5000 personal digital certificates paid by the state will be allocated. Personal digital certificates - incentive payments that the state will devote to the development of key competencies of the digital economy, such as basic programming, the basics of working with data or communication in modern digital environments. Until 2024, it is planned to provide up to a million personal digital certificates. In 2019 a free online educational resource for the development of digital literacy will be launched. It will provide courses to help you learn data manipulation skills, programming basics and how to use the Internet safely. The plans are that in 2019 , this resource will have at least ten million online listeners.

As a result, the Russians will have the opportunity to form individual development paths based on personal profiles. A person with the help of a certificate will be able to go through a training program online or apply in person to the appropriate organization providing educational services that meet the needs of a new type of economy.

In view of the above, at the regional level, it is necessary to develop programs to support distance employment. An effective way to solve the problem of employment in single-industry towns can be the development of flexible employment. Flexible forms of employment - forms of labor use of the workforce based on the use of nonstandard organizational and legal conditions for the employment of workers (Garifullina, 2014). The main forms of flexible employment includes work with a flexible schedule of working hours, home work, work on calls, shift and expeditionary activity, temporary employment, part-time work.

Wider use of forms of flexible employment will help to attract labor force from the category of socially vulnerable layers of the population, such as youth, women raising children, pensioners, people with disabilities. The prerequisite for the wider use of forms of flexible employment is the creation and development of a regulatory framework, government support measures for organizations that employ socially vulnerable segments of the population. 


\section{Conclusion}

In single-industry towns, it is necessary to reduce inefficient "social employment" by creating highly productive jobs and redistributing the wage fund to the benefit of creative workers, while introducing a system for the retraining of the released personnel in other categories, mainly those engaged in physical and routine labor, and the development of self-employment.

Employment management policies in single-industry towns should be regard the issue of precarious and informal employment, and include measures aimed at solving the issues related to self-employment of the population.

\section{References:}

Aksyanova, A.V., Chekhlomin, S.V. 2018. Methods for assessing the economic attractiveness of single-industry towns for the population. Bulletin of KemSU, Series: Political, Sociological, and Economic Sciences, 2, DOI 10.21603 / 2500-3372-20182-52-58.

Babynina, L.S. 2014. Theoretical and methodological foundations of the compensation model of remuneration. Moscow, MGIIT Yu.A. Senkevich.

Bauman, Z. 2005. Individualized society. Moscow, Logos, 390.

Bobkov, V.N. 2017. Employment instability: international and Russian contexts of the future world of work. Moscow, Publishing House Real Print, 560.

Bykova, O.N., Ermolaeva, T.K., Scriabin, O.O. 2018. Mechanisms of overcoming social restrictions on the way of innovative development of monotrends. Scientific research and development. Economy of the company, 4(7), 12-16.

Bykova, O.N., Suslova, S. 2011. Logistic technology transfer as a method of diffusion of innovations. Logistics, 8(61), 23-25.

Chelpanova, D.D., Grevtsova, T.E. 2018. Actual problems of the single-industry town of Gukovo, Rostov Region: opinions of residents. Bulletin of KemSU, Series: Political, Sociological, and Economic Sciences, 2, DOI: 10.21603 / 2500-3372-2018-2-40-44.

Crying, V.I. 2005. Unemployment: theory and modern Russian practice (socio-economic aspect). Moscow, RAGS, 384.

Dobrycheva, I.V. 2018. The influence of TOSER status on the labor market of singleindustry towns. Bulletin of Omsk State University. Series: Economics, 2, 128-142, DOI: 10.25513 / 18123988.2018.2.130-142.

Fainburg, G.Z. 2017. The rapid growth of precariat as a threat to the well-being of modern and future society (based on labor protection materials). Towards the future, Forecasting in sociological research, Materials of the VII international sociological Grushinsky conference, 1342-1345.

Fedchenko, A.A. 2014. The role of precarious employment in the clustering of society. Living standards of the population of Russian regions. Social quality and standard of living, 4, 54-64.

Garifullina, N.Yu. 2014. Socio-economic development of single-industry towns as a potential development of the region's economy. Demand and supply in the labor market and the market of educational services in the regions of Russia: Sat. reports based on the materials of the Eleventh All-Russian Scientific and Practical Internet Conference, Petrozavodsk, PetrSU, B1, 42-56. 
Gimpelson, V.E., Sharunina, A.V. 2015. Flows in the Russian labor market: 2000-2012. HSE Journal of Economics, 3(19), 313-348.

Glinskaya, M.I. 2018. Analysis of the spread of informal employment in Russia: causes, forms and areas of concentration. Vestnik REU G.V. Plekhanov, 4(100), 124-134.

Herrman, P., Kalaycioglu, S. 2011. Precarity: More Than a Challenge of Social Security. Cynicism of EU Concept of Economic Freedom. Bremen, Europäischer Hochschulverlag.

Kotvanova, S.G. 2014. Informal employment and hidden unemployment. Barnaul, AAEP Publishing House, 160.

Maslova, A.N. 2011. Monotowns in Russia: problems and solutions. Outlines of global transformations: politics, economics, law, 5, 16-28.

Nikolaeva, E.E. 2018. Monotowns: socio-economic problems and prospects (on the example of the Ivanovo region). Bulletin of KemSU, Series: Political, Sociological, and Economic Sciences, 1, DOI: 10.21603 / 2500-3372-2018-1-137-142.

Odegov, Yu.G., Babynina, L.S. 2018. Unstable employment as a possible factor in using the labor potential of the youth of Russia. Monitoring of public opinion: Economic and social changes, 4(146), 386-409, DOI:10.14515/monitoring.2018.4.2

Oganyan, K.M., Streltsov, N.M. 2008. Employment and its regulation. St. Petersburg, Business Press, 372.

Peredelskaya, A. 2016. Single-industry towns under post-industrialism: how are they saved in different countries of the world? Political Russia - a socio-political online magazine, September 4.

Repnikova, V.M., Bykova, O.N., Skryabin, O.O., Morkovkin, D.E., Novak, L.V. 2019. Strategic aspects of innovative development of entrepreneurial entities in modern conditions. International Journal of Engineering and Advanced Technology, 4(8), 3235 .

Rybakovsky, L.L. 2012. Migration: forecasts, factors, politics. Moscow, Nauka.

Sennett, R. 1998. The Corrosion of Character: The Personal Consequences of Work in the New Capitalism. New York, W.W. Norton \& Company.

Shirokova, O.V., Korolkova, A.A. 2016. The problem of hidden unemployment at the state and regional levels. In the collection: Autumn economic readings Materials of the International scientific-practical conference, 31-36.

Standing, G. 2011. The Precariat: The New Dangerous Class, New York, Bloomsbury Academic, 192.

Ustinova, K.A., Gordievskaya, A.N. 2016. Unstable employment: restrictions on the reproduction of labor potential. Social space, 3(5), 9.

Zvyagintseva, O.P., Lebedev, K.A., Blokhina, O.A., Bannikov, S.A., Repnikova, V.M. Development of small businesses at the regional level. International Journal of Civil Engineering and Technology, 9(13), 119-126. 